\title{
Analysis of gene expression during aging of CGNs in culture: implication of SLIT2 and NPY in senescence
}

\author{
K. Preeti Gupta $\cdot$ Pankaj Singh Dholaniya • \\ Anil Chekuri • Anand K. Kondapi
}

Received: 8 February 2015 / Accepted: 27 April 2015 / Published online: 6 June 2015

(C) American Aging Association 2015

\begin{abstract}
Senescence is the major key factor that leads to the loss of neurons throughout aging. Cellular senescence is not the consequence of single cause, but there are multiple aspects which may induce senescence in a cell. Various causes such as gene expression, molecular interactions and protein processing and chromatin organization are described as causal factor for senescence. It is well known that the damage to the nuclear or mitochondrial DNA contributes to the aging either directly by inducing the apoptosis/cellular senescence or indirectly by altering cellular functions. The significant nuclear DNA damage with the age is directly associated with the continuous declining in DNA repair. The continuous decline in expression of topoisomerase 2 beta (Topo II $\beta$ ) in cultured cerebellar granule neurons over time indicated the decline in the repair of damage DNA. DNA Topo II $\beta$ is an enzyme that is crucial for solving topological problems of DNA and thus has an important role in DNA repair. The enzyme is predominantly present in non-proliferating cells such as neurons. In this paper, we have studied the genes which were differentially expressed over time in cultured cerebellar granule neurons (CGNs) and identified potential genes associated with the senescence. Our results showed that the two
\end{abstract}

K. Preeti Gupta and Pankaj Singh Dholaniya contributed equally to this work.

K. P. Gupta • P. S. Dholaniya • A. Chekuri ·

A. K. Kondapi $(\triangle)$

Department of Biotechnology and Bioinformatics, School of

Life Sciences, University of Hyderabad, Hyderabad 500046

Andhra Pradesh, India

e-mail: akondapi@gmail.com genes neuropeptide Y (Npy) and Slit homolog 2 (Drosophila) (Slit2) gradually increase during aging, and upon suppression of these two genes, there was gradual increase in cell viability along with restoration of the expression of Topo II $\beta$ and potential repair proteins.

Keywords Senescence - Oxidative stress · Ageing · ROS $\cdot$ Cerebellar granule neurons
Abbreviations
CGNs Cerebellar granule neurons
DSBs Double strand breaks
ROS Reactive oxygen species
SSBs Single-strand breaks
Topo II $\beta$ Topoisomerase II $\beta$

\section{Introduction}

Over four decades ago, senescence was first described by Hayflick and colleagues as limited ability of cells to proliferate in culture (Hayflick 1965). Cellular senescence was proposed to be an anticancer or a tumor suppressing mechanism as it stops incipient cancer cells from proliferating (Braig and Schmitt 2006) and, hence, was considered beneficial. Senescence was proposed to recapitulate ageing of cells in vivo (Campisi and d'Adda di Fagagna 2007). Severe DNA damage especially double-stranded DNA breaks (DSBs) provide constitutive signals to p53 to maintain senescence (Herbig et al. 
2004; Rodier et al. 2007). It may either be a dysfunctional telomere initiated DNA damage response (Herbig et al. 2004) or histone deacetylase inhibition (HDAi) promoting euchromatin formation (Munro et al. 2004) or oncogene-induced-like overexpression of oncogenic p21 Rat sarcoma (Ras) (Lin et al. 1998; Serrano et al. 1997; Zhu et al. 1998) or a sustained signaling by antiproliferative cytokines like interferon $\beta$, which in turn increases intracellular reactive oxygen species (ROS). Any of these reasons could ultimately result in senescence. Senescence may manifest as growth arrest and resistance to cell death mechanisms like apoptosis and necrosis. The cells display inability to progress through cell cycle in spite of being metabolically active (Di Micco et al. 2008; Herbig et al. 2004). Such an inability could be due to a G2-M arrest like in mouse fibroblasts with accumulation of G1 DNA (Wada et al. 2004). One of the major problems posed by senescence is resistance to apoptosis, which varies from cell to cell. Senescent human fibroblasts are resistant to apoptosis due to growth factor deprivation and oxidative stress but are susceptible to FAS death receptor-mediated apoptosis (Chen et al. 2000; Tepper et al. 2000). However, the factor that determines the fate of the cell is not very clear. The senescent cells are also characteristic of altered expression of cell cycle inhibitors and activators like $\mathrm{p} 21$ and $\mathrm{p} 16$; these proteins indeed are regulated by tumor suppressor genes viz., p53 and pRB (Campisi and d'Adda di Fagagna 2007). In addition, senescent cells may overexpress genes that encode secretory proteins, which in turn alter tissue microenvironment (Chang et al. 2002; Yoon et al. 2004; Zhang et al. 2003). For example, an in vivo study in baboons (Herbig et al. 2006) revealed that senescent cells account to more than $15 \%$ of cells in aged animals.

Physiologically, senescence may manifest in diseased conditions too like atherosclerosis, obesity, and cancer. Atherosclerosis is a chronic inflammatory disease of the vascular smooth muscle vessels derived from human atherosclerotic plaques. These cells showed an impaired growth in vitro and underwent senescence earlier than cells from normal vessels (Chung et al. 2009; Minamino and Komuro 2007). Evidence for obesity and its connection with accumulated senescent preadipocytes and endothelial cells and increased secretion of inflammatory cytokines and chemokines was reported (Tchkonia et al. 2010). Excessive calorie intake led to accumulation of oxidative stress in adipocyte tissue of mice with type 2 diabetes like disease and promoted senescence-like changes. Cells undergoing reprogramming during senescence displayed not only permanent growth arrest but also changed morphology and function (Campisi and d'Adda di Fagagna 2007). A striking increase in the secretion of pro-inflammatory cytokines by senescent cells exerts harmful effects on the local environment. This was termed as senescence-associated secretory phenotype (SASP) (Davalos et al. 2010). In all, it appears that senescent cells create an environment that supports the development of age-related diseases which may manifest in reduced organ function (Franceschi et al. 2000). Hence, senescent cells may act as a tumor suppressing mechanism (since these cells cannot divide) and support cancer development (via the senescence associated secretome) (Sikora et al. 2011).

In vivo senescent cells are found in humans, baboons, mouse skin, human, animal skeletal muscle, fat tissue, and liver (Jeyapalan and Sedivy 2008). The identification of senescent cells in vivo is of vital importance owing to the deleterious effects of senescent cells. The hallmark of cellular senescence is primarily altered cellular morphology (enlarged-flat-multi-vacuolated- multinucleolated), elevated senescence associate beta galactosidase (SA- $\beta$-Gal) activity, accumulation of DNA damage foci, $\gamma \mathrm{H} 2 \mathrm{AX}$ senescence-associated heterochromatin foci (SAHFs), chromosomal instability, and induction of inflammatory secretome. A detailed list of markers for senescence has been given in Table 1 . However, a plethora of these markers are not senescence specific and cannot be verified in vivo $(\gamma \mathrm{H} 2 \mathrm{AX}$ and SAHF) (Kosar et al. 2011). Further, there is a requirement of validated markers specific to neuronal senescence.

Lack of quantitative tests for reliable candidate markers for identification of senescent cells is a major drawback in cell population studies (Lawless et al. 2010). Therefore, this work was conceptualized to identify novel biomarkers for neuronal ageing and neurodegenerative diseases. Since senescence is a multi-molecular processes involving several pathways, a trasciptome analysis using microarray approach was employed for an insight into overall expression profile of genes, which were further analyzed through pathways identification, clustering, real-time PCR-based validation, and specific transcription silencing. Based on such analysis, a few 
Table 1 Previously identified markers for senescence

\begin{tabular}{|c|c|c|c|}
\hline S. No & Marker & Reference & Expression seen in \\
\hline 1 & $\uparrow$ TIFS (Telomere dysfunction-induced foci) & (Herbig et al. 2006) & p53-mediated senescence \\
\hline 2 & $\begin{array}{l}\uparrow \text { SAHF (senescence-associated } \\
\text { heterochromatin foci) }\end{array}$ & (Funayama and Ishikawa 2007) & $\begin{array}{l}\text { Replicative senescence P16-mediated } \\
\text { senescence }\end{array}$ \\
\hline 3 & $\uparrow$ SA- $\beta-$ Gal & $\begin{array}{l}\text { (Dimri et al. 1995; } \\
\text { Wang et al. 2009) }\end{array}$ & $\begin{array}{l}\text { Cannot be detected by histochemical } \\
\text { staining may be induced by stress } \\
\text { in culture }\end{array}$ \\
\hline 4 & $\gamma \mathrm{H} 2 \mathrm{AX}$ (phosphorylated histone H2AX) & $\begin{array}{l}\text { (Wang et al. 2009); } \\
\quad \text { (Nakamura et al. 2008) }\end{array}$ & DSB marker \\
\hline 5 & A2M (activated telangiectasia-mutated kinase) & (Di Micco et al. 2008) & Senescent fibroblasts + ATM pathway \\
\hline 6 & Heterochromatin loss & (Villeponteau 1997) & \\
\hline 7 & p16 (cyclin-dependent kinase inhibitors) & (Beausejour et al. 2003) & $\begin{array}{l}\text { Not expressed in all the cells seen in } \\
\text { tumor cells only that have lost } \mathrm{pRb} \\
\text { function }\end{array}$ \\
\hline 8 & Intracellular $\mathrm{Ca} 2+$ & (Thibault et al. 2001) & Neurons \\
\hline 9 & TopoII $\beta$ & (Bhanu et al. 2010) & CGNs \\
\hline 10 & $\begin{array}{l}\text { DEC1 (differentiated embryo-chondrocyte } \\
\quad \text { expressed-1), p15 }\end{array}$ & (Collado and Serrano 2006) & $\begin{array}{l}\text { Promising but expressed in oncogene } \\
\text {-induced senescence }\end{array}$ \\
\hline 11 & P16INK4A (cyclin-dependent kinase inhibitors) & $\begin{array}{l}\text { (Ressler et al. 2006) } \\
\text { (Yang et al. 2008) }\end{array}$ & Replicative and oncogene-induced senescence \\
\hline
\end{tabular}

genes have been identified as markers-associated senescence, which will be of potential interest.

\section{Materials and methods}

Chemicals

Reagents used were poly-D-lysine, Bradford reagent, DAPI (Sigma Chemical Co., MO, USA); Earle's balanced salt solution (EBSS), minimal essential medium (MEM), penicillin streptomycin, fetal bovine serum (FBS), Trypsin, Glutamax (GIBCO, NY, USA); dNTPs (Fermentas, MD, USA); pure enzymes T4 DNA ligase (Invitrogen, NY, USA); and T4 polynucleotide kinase (Bangalore Genei, India). Real-time PCR reagents were from Applied Biosystems Inc., USA. All the other chemicals and reagents were of biochemical grade.

\section{Animals}

Wistar rats were maintained in accordance with the Institutional Animal Ethics Committee approval, University of Hyderabad. The rats were provided by $\mathrm{Na}-$ tional Institute of Nutrition, Hyderabad, India (NIN, Hyderabad) and maintained in a pathogen-free environment with a 12-h light and darkness cycle. Food and water were provided ad libitum.

\section{Cell culture}

Primary cultured granule neurons (CGNs) were prepared from the cerebella of postnatal 6- to 8-day-old pups by cervical dislocation, and the tissue was dissected and stored in ice-cold EBSS. The tissue was minced in $0.1 \%$ trypsin as previously described (Wilkin 1995). The CGN cultures were prepared by triturating and diluting the cell pellet with the plating medium (MEM supplemented with $10 \%$ FBS, $33 \mathrm{mM}$ glucose, $24.5 \mathrm{mM} \mathrm{KCl}, 1 \times$ Glutamax, 5 and $5000 \mathrm{U} / \mathrm{mL}$ of penicillin streptomycin). Cells were plated at $2.5 \times$ $10^{6}$ cells $/ 60-\mathrm{mm}$ dish and were incubated at $37{ }^{\circ} \mathrm{C}$ in $5 \%$ humidified $\mathrm{CO}_{2}$ atmosphere. After $24 \mathrm{~h}$ of plating, the entire medium was changed, and $10 \mu \mathrm{M}$ of cytosine arabinoside, a mitotic inhibitor, was added to inhibit the growth of astrocytes and glial cells. Neuronal cell cultures were fed weekly once by replacing with fresh culture medium. Day of neuronal isolation was considered as day 1, and CGNs were cultured for 5 weeks $(5 \mathrm{~W})$. The culture was split into five dishes to carry out experiments. Day of neuronal isolation was considered as day 1 , and CGNs were aged for 5 weeks ( $5 \mathrm{~W}$ ). Cells 
were pelleted week-wise (at an interval of 7 days) starting from day 1 , correspondingly $1 \mathrm{~W}$ (7th day), $2 \mathrm{~W}$ (14th day), $3 \mathrm{~W}$ (21st day), $4 \mathrm{~W}$ (28th day), $5 \mathrm{~W}$ (35th day), and $6 \mathrm{~W}$ (42nd day) in culture.

\section{Microarray analysis}

First week (day 7) was regarded as control with which second (14th day), third (21st day), and fourth week (28th day) samples were compared. Since CGNs were attained senescence at 4 weeks as assessed by SA- $\beta$-Gal staining and Fura- 2 AMbased intracellular calcium levels (Bhanu et al. 2010), 1st week to 4 weeks of CGNs were used for microarray analysis. The samples were collected in duplicate and processed for microarray analysis at Genotypic Technology Pvt Ltd, Bangalore, India, using Whole Rat Genome Microarray Kit, $4 \times 44 \mathrm{~K}$ array manufactured by Agilent 60-mer SurePrint technology (Cat no-G4131F). Briefly, total RNA was isolated from control and aged cells by using TRIZOL (Invitrogen, NY, USA) as per manufacturer's protocol. Using RNeasy mini kit columns (Qiagen, Hilden, Germany), RNA samples were further purified. Total RNA integrity was assessed using RNA 6000 Nano LabChip on the 2100 Bioanalyzer (Agilent, Palo Alto, CA) following the manufacturer's protocol. Total RNA purity was assessed by the NanoDrop ${ }^{\circledR}$ ND-1000 UV-Vis Spectrophotometer (Nanodrop Technologies, Rockland, USA). All the samples were analyzed in duplicate. The samples were labeled, hybridized, and scanned for fluorescent signals.

Data was analyzed using GeneSpring GX version 11.5 (Agilent Technologies) and Microsoft Excel. Fold change used for upregulation was $>0.8$ and downregulation $<0.8$ in each of the replicates and $>1$ in the Geomean fold of the replicated samples. $P$ value $<0.05$ was considered statistically significant. Microarray data was divided into three sets: Set $1-$ First week was taken as control and compared with weeks 2, 3, and 4; Set 2-Second week was taken as control and compared with weeks 3 and 4; Set 3-Third week was taken as control and compared with week 4 (Fig. 1). Genes were classified based on functional category and pathways using GeneSpring GX Software and Biointerpreter (Agilent Technologies).
Real-time PCR analysis

The microarray cDNA analysis was validated by quantitative real-time PCR (qPCR). Ten microliters of cDNA synthesis was carried out using $1 \mu \mathrm{g}$ of total RNA, random hexamers, and SuperScript ${ }^{\mathrm{TM}}$ First-Strand Synthesis System (Invitrogen, NY, USA) using gene specific primers as in Table 2 (Eurofins Genomics, Bangalore, India) and Power SYBR green PCR Master Mix (Applied Biosystem, CA, USA). Absence of genomic DNA in total RNA was ensured by DNase I treatment (Fermentas, GmbH, Germany). 18s rRNA was used as an internal control. To ensure no contamination of PCR reagents with the cDNA, no template controls (NTC) were set up. PCR analysis was performed with $\mathrm{ABI}$ Prism H7500 fast thermal cycler (Applied Biosystem, CA, USA). Each sample was run in triplicate in a final volume of $10 \mu \mathrm{L}$ containing $0.2 \mu \mathrm{L}$ of first-strand cDNA template, 20 pmol of each primer, and $5 \mu \mathrm{L}$ of Power SYBR Green PCR master mix. Fluorescence resulting from DNA amplification was analyzed. Relative fold change was assayed using $2^{-\Delta \Delta \mathrm{CT}}$ method (Livak and Schmittgen 2001). Primers used for realtime PCR are given in Table 2.

\section{Statistical analysis}

The experiments were performed in triplicate and repeated independently thrice. Data was averaged and presented as mean \pm SD. Statistical analysis was done using GraphPad Prism 5 (demo version, GraphPad Software, San Diego, CA, USA), one-way ANOVA with Tukey's post hoc test. $P$ value $<0.05$ was considered statistically significant. The test was used to compare control with Topo II $\beta$ downregulated condition at a particular treatment level and with $2-5 \mathrm{~W}$ aged cells.

\section{RNA inhibition using siRNA}

We have used double strand siRNA oligos for transient downregulation of indicated genes in rat CGNs. Lipofectamine 2000 (Invitrogen) was used for transfecting the double-strand siRNA oligos. Cultures, 1 day after plating were used for transfection as standardized in our lab (Mandraju et al. 2008) (Table 3). Double-strand siRNA oligos were synthesized as described earlier (Donze and Picard 2002). For this, desalted DNA oligonucleotides were obtained from Sigma (India). The oligonucleotide-directed production of small RNA 

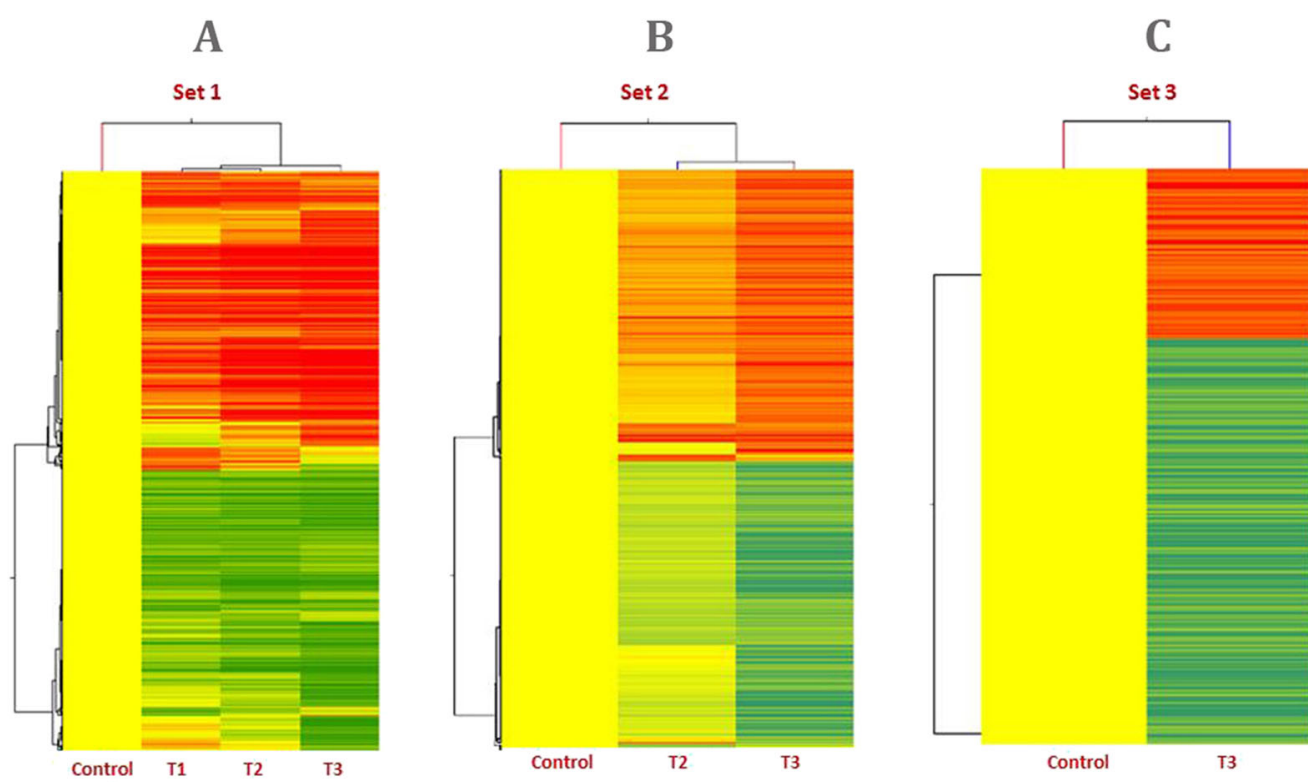

\begin{tabular}{|c|c|c|}
\hline $\begin{array}{c}\text { Samples } \\
\text { hybridized }\end{array}$ & Up & Down \\
\hline T1 & 2773 & 2547 \\
\hline T2 & 4300 & 3609 \\
\hline T3 & 5165 & 4500 \\
\hline
\end{tabular}

\begin{tabular}{|c|c|c|}
\hline $\begin{array}{c}\text { Samples } \\
\text { hybridized }\end{array}$ & Up & Down \\
\hline T2 & 1021 & 415 \\
\hline T3 & 2840 & 2331 \\
\hline
\end{tabular}

\begin{tabular}{|c|c|c|}
\hline $\begin{array}{c}\text { Samples } \\
\text { hybridized }\end{array}$ & Up & Down \\
\hline T3 & 522 & 1253 \\
\hline
\end{tabular}

Fig. 1 Heat map of differentially expressed genes in ageing CGNs. A heat map was created for the entire genome to display those statistically significant ( $P$ value $<0.05$ with multiple testing corrections applied). Fold change used for upregulation and downregulation was 0.8 in each of the replicates and $>1$ in the Geomean fold of the replicated samples. Normalized expression signals are represented on a log scale for which colder colors correspond to lower levels of expression and warmer colors correspond to higher levels of expression. Genes were clustered, and heat maps were generated using Cluster v3.0/TreeView (de Hoon et al. 2004; Eisen et al. 1998). Panels a-c show comparisons of other weeks with 1 , 2 , and $3 \mathrm{~W}$ as in set 1 , set 2 , and set 3 , respectively

were annealed by mixing both crude transcription reactions, heating at $95^{\circ} \mathrm{C}$ for $5 \mathrm{~min}$ followed by $1 \mathrm{~h}$ at $37^{\circ} \mathrm{C}$ to obtain 'T7 RNA polymerase synthesized small interfering double-stranded RNA' (T7 siRNA). The mixture $(100 \mu \mathrm{L})$ was then adjusted to $0.2 \mathrm{M}$ sodium acetate, $\mathrm{pH}$ 5.2, and precipitated with 2.5 volume of ethanol. After centrifugation, the pellet was washed once with $70 \%$ ethanol, dried, and resuspended in $50 \mu \mathrm{L}$ of water.

In case of gene-specific knockdown studies, at 3 weeks after culturing, the neurons were treated with gene specific SiRNA $(0.1-1 \mu \mathrm{M})$ using Lipofectamine2000 (Invitrogen, cat. no. 11668) as transfection agent and also with $0.5 \mu \mathrm{M}$ of non-silencing siRNA (scrambled) as control. The effect of Topo II $\beta$ or senescence-associated gene-specific siRNA on the viability of granule neurons in culture was determined using cell viability assay described above (Mosmann 1983). Cultured CGNs in poly-l-lysine coated 24 well plates after treatment at 3 weeks were assessed for cell 
Table 2 Primers used for real-time PCR

\begin{tabular}{|c|c|c|c|c|}
\hline S. No & Gene & Forward primer $\left(5^{\prime} \rightarrow 3^{\prime}\right)$ & Reverse primer $\left(5^{\prime} \rightarrow 3^{\prime}\right)$ & Amplicon size \\
\hline 1 & UNG & CGC ACA CCA AGC CAA TTC CCA TAA & AGG TTC TGA TTC AGC CAC GAC ACA & 81 \\
\hline 2 & SMUG & TTT CCA GAG CCT GTG GGT GTC ATC TA & TTG GCA GTA GCG AGT CAC GTA GTT & 84 \\
\hline 3 & APEX & GTT CTT CCT CAC CAA TGC CAT AAG AG & AGG CTT GGA TTG GGT AAA GGA AGA AGC & 215 \\
\hline 4 & POL B & CAC AGC TCA ATG GCA CCT AAC & AGT GAC CAG ACG CTG TGA TG & 220 \\
\hline 5 & POL M & AGA GGT GAC ACA TGT GGT GAT GGA & TCC TGC TGC CAT GCT CTC TGT AAA & 142 \\
\hline 6 & POL L & AGG GTT CCT CAC AGA TGA CTT GGT & AAA CTC ACT GTA GGG CAC CAC GAT & 136 \\
\hline 7 & LIG 1 & AGA CAG CAG AGG CCA GAA AGA TGT & TCT GGG AGA CTT TCC AAG CCA TGT & 130 \\
\hline 8 & LIG 3 & TAC TGG AGG CAG CAA TGG TGA GAA & TTC TTG GCA CTG GCA GAG GAC TTA & 102 \\
\hline 9 & TOP2B & GAC AGA GGA AGG TAG TAG AGC CTG & CGT TTT CTT CGG TTT CTT GCT GGC & 168 \\
\hline 10 & A2M & $\begin{array}{l}\text { TCA CTC ATC CTG TTG TCC GCA ATG } \\
\text { CCC TCT }\end{array}$ & $\begin{array}{l}\text { ACC AGC AAG GGC AAA TGC ATA GGC } \\
\text { CAA CA }\end{array}$ & 128 \\
\hline 11 & GNA14 & $\begin{array}{l}\text { ACC AAA GCA AGA TGT CAA AGC TGC } \\
\text { CAG GGA }\end{array}$ & $\begin{array}{l}\text { TCC TTG ACA GCA GCA AAC ACG AAG } \\
\text { CGG AT }\end{array}$ & 147 \\
\hline 12 & GRIA1 & $\begin{array}{l}\text { ATG CCA ACC AGT TTG AGG GCA ATG } \\
\text { ACC GCT }\end{array}$ & $\begin{array}{l}\text { TTC TCC CAC CAT GCC ATT CCA AGC } \\
\text { CTT TGT }\end{array}$ & 167 \\
\hline 13 & MASP & $\begin{array}{l}\text { TGC CGA GTG GAA TGC AGT GGC AAT } \\
\text { CTC TT }\end{array}$ & $\begin{array}{l}\text { AGG GCA CCT CGG GAT GGT CTT CAA } \\
\text { TGT CAA }\end{array}$ & 184 \\
\hline 14 & NPY & $\begin{array}{l}\text { TGC TCG TGT GTT TGG GCA TTC TGG } \\
\text { CTG A }\end{array}$ & $\begin{array}{l}\text { ATC AGT GTC TCA GGG CTG GAT CTC } \\
\text { TTG CCA }\end{array}$ & 169 \\
\hline 15 & SLIT2 & $\begin{array}{l}\text { AGA ACG GCA CCA GCT TCC ATG GCT } \\
\text { GTA T }\end{array}$ & $\begin{array}{l}\text { TGG GCA CAC ACT TTC TTG TGG CAT } \\
\text { GGT TCA }\end{array}$ & 133 \\
\hline 16 & GLB & $\begin{array}{l}\text { TCA AGG ATG GGC AGC CAT TCC GCT } \\
\text { ACA T }\end{array}$ & $\begin{array}{l}\text { TGG ATT GCA TCC AGC CCA GCC ATC } \\
\text { TTC AT }\end{array}$ & 118 \\
\hline 17 & $18 \mathrm{~S}$ & GCT ACC ACA TCC AAG GAA GGC AGC & CGG CTG CTG GCA CCA GAC TTG & 200 \\
\hline
\end{tabular}

viability and gene expression at fourth, fifth, and sixth weeks in culture.

\section{Cell viability assay}

The viability of granule neurons in culture was estimated by the redox activity of mitochondria in reducing MTT (3-(4,5-Dimethylthiazol-2-yl)-2,5-diphenyl tetrazolium bromide) (Sigma) in viable cells. Cells were cultured in poly-lysine coated 24 well plates $(1 \times$ $10^{5}$ cells per well). After the cultures reached indicated age, $500 \mu \mathrm{L}$ of $0.5 \mathrm{mg} / \mathrm{mL}$ of MTT in fresh medium was added to each well, and the cells were incubated at $37^{\circ} \mathrm{C}$ for $4 \mathrm{~h}$. The plates were then centrifuged at $1500 \mathrm{rpm}$ for $20 \mathrm{~min}$ at room temperature, and the medium was carefully removed. Dimethyl sulfoxide (DMSO) $(500 \mu \mathrm{L})$ was then added to each well to dissolve the formazan crystals. The DMSO-dissolved formazan crystals were read immediately at $540 \mathrm{~nm}$ with DMSO as blank on a spectrophotometer (JASCO, Japan).

\section{Results}

Differential gene expression in CGNs

CGNs were chosen for this study as primary cultures of postnatal rat cerebellum, they form an excellent model system for molecular and cell biological studies of neuronal development and function. Many fundamental insights into the phenomena of apoptosis, migration, and differentiation in neurons in the mammalian central nervous system have come from investigating granule neurons in vitro. These cells may prove invaluable in uncovering the senescence pathways. Keeping this in view, the ageing CGNs were processed for microarray analysis, and the data was subjected to clustering and differential expression.

Differential gene expression allows researchers to look at a specific gene's behavior over a set of samples. However, it allows one to look at only one gene at a time. So, there exists a need to look at a more complex network of genetic changes. For example, genetic 
Table 3 SiRNA table

\begin{tabular}{|c|c|c|}
\hline Name & siRNA sense template sequence & siRNA antisense template sequence \\
\hline TopoIIß siRNA & $\begin{array}{l}\text { 5'-AAA GCT TAA CAA TCA AGC } \\
\text { CCG CTA TAG TGA GTC GTA TTA-3' }\end{array}$ & $\begin{array}{l}\text { 5'-AAC GGG CTT GAT TGT TAA GCT CTA } \\
\text { TAG TGA GTC GTA TTA-3' }\end{array}$ \\
\hline TopoIIß scrambled siRNA & $\begin{array}{l}\text { 5'-ACA CTC GAT CAA TCC AAG GAA } \\
\text { CTA TAG GGA ATC GAA ATA-3' }\end{array}$ & $\begin{array}{l}\text { 5'-CAC TGG ATT GAT CGA GAT GTT CTA } \\
\text { TAG TGA GTC GTA TTA-3' }\end{array}$ \\
\hline SLIT 2 siRNA & $\begin{array}{l}\text { 5'-ATT GAT TCC CCA ACA ATT CAG TAG } \\
\text { TAG TGA GTT ATA-3' }\end{array}$ & $\begin{array}{l}\text { 5'-AAT TGT CTA CAT CCA GAA TAT ATA } \\
\text { TGG AGA GGC ATA ATA-3' }\end{array}$ \\
\hline SLIT 2 scrambled siRNA & $\begin{array}{l}\text { 5'-TAT GGT TCA ACA CCA ATT CCG CAG } \\
\text { CCG TTA ATT AAA TAA-3' }\end{array}$ & $\begin{array}{l}\text { 5'-CAC TGG ATT GAT CGA GAT GTT CTA } \\
\text { TAG TGA GTC GTA CTA-3' }\end{array}$ \\
\hline MASP siRNA & $\begin{array}{l}\text { 5'-GAA AAT CTA ATA CCA ATC TTG AAG } \\
\text { AAG CAA ACC CGT ATA-3' }\end{array}$ & $\begin{array}{l}\text { 5'-AAC TAG CCT GAC AGC GAT ATT CTA } \\
\text { AAG CAA GAC ATA GTA-3' }\end{array}$ \\
\hline MASP scrambled siRNA & $\begin{array}{l}\text { 5'-AAT TAT TCC CCA TCA ACT CTG AAG } \\
\text { TTG ATA ATT TTA CCT-3' }\end{array}$ & $\begin{array}{l}\text { 5'-GAC TAG AAT GAC AGC TAT ACG CTA } \\
\text { CCG CAA GAC CTA CCA-3' }\end{array}$ \\
\hline GLB siRNA & $\begin{array}{l}\text { 5'-CAT TTT TCC TTA TCA ACT CGG CAG } \\
\text { TAG ACA AAT CTA GCT-3' }\end{array}$ & $\begin{array}{l}\text { 5'-TAC GAC TCT GAC TGC GGT CAT CAA } \\
\text { AAG CGG AAC GTA GTA-3' }\end{array}$ \\
\hline GLB scrambled siRNA & $\begin{array}{l}\text { 5'-ATC AAG CTT TAC AGC AAT CCT TTA } \\
\text { AAG TGA AAC ATA TTA-3' }\end{array}$ & $\begin{array}{l}\text { 5'-CTT AGT AGA CCA TCAATT ACG CAG } \\
\text { TTG ATA ATT CCT TAT-3' }\end{array}$ \\
\hline GRIA1 siRNA & $\begin{array}{l}\text { 5'-AAT TAT TCC CCA TCA ACT CTG AAG } \\
\text { TTG ATA ATT TTA CCT-3' }\end{array}$ & $\begin{array}{l}\text { 5'-CAC TGG ATT GAT CGA GAT GTT CTA } \\
\text { TAG TGA GTC GTA TTA-3' }\end{array}$ \\
\hline GRIA1 scrambled siRNA & $\begin{array}{l}\text { 5'-TAC GTG GTT AAT CCT GAT GTT CTA } \\
\text { TAG TGA GTC ATA ATG-3' }\end{array}$ & $\begin{array}{l}\text { 5'-TTC TAC CAT TTC ACC GGT ATT CTA } \\
\text { AAG CAA GAC GTA GTC-3' }\end{array}$ \\
\hline A2M siRNA & $\begin{array}{l}\text { 5'-CTC AAA CAT AAT AGC GAT AAT CCA } \\
\text { AGG GAA GAC ATC TTA-3' }\end{array}$ & $\begin{array}{l}\text { 5'-AGA GGT TCA ACA GCA AGT CCG CTG } \\
\text { CCG ATA ATA ACC TAA-3' }\end{array}$ \\
\hline A2M scrambled siRNA & $\begin{array}{l}\text { 5'-TAT TCT TCC CTA TCA AAT CTG TGG } \\
\text { ATG ATA ATT AGA GCT-3' }\end{array}$ & $\begin{array}{l}\text { 5'-GAA AAT CTA ATA CCA ATC TTG AAG } \\
\text { AAG CAA ACC CGT ATA-3' }\end{array}$ \\
\hline GNA14 siRNA & $\begin{array}{l}\text { 5'-AAC TAG CCT GAC AGC GAT ATT CTA } \\
\text { AAG CAA GAC ATA GTA-3' }\end{array}$ & $\begin{array}{l}\text { 5'-TAC AAG CCA GTA ATA ATC CAG AAG } \\
\text { TAG CAT TCC GGT GTT-3' }\end{array}$ \\
\hline GNA14 scrambled siRNA & $\begin{array}{l}\text { 5'-GAT GGT TCA ACA CCA ATT CCG CAG } \\
\text { CCG TTA ATT ATT TAA-3' }\end{array}$ & $\begin{array}{l}\text { 5'-TAT GGT TTC GCA TAA ACT GTG TAG } \\
\text { TTG CTA ATT TTA CCT-3' }\end{array}$ \\
\hline NPY siRNA & $\begin{array}{l}\text { 5'-CGA CGT TTA AAG CCA ATG ATC AAG } \\
\text { TAG GGA ACA TGT CTA-3' }\end{array}$ & $\begin{array}{l}\text { 5'-AAC GGG CTT GAT TGT TAA GCT CTA } \\
\text { TAG TGA GTC GTA TTA-3' }\end{array}$ \\
\hline NPY scrambled siRNA & $\begin{array}{l}\text { 5'-AAT AAA TCC CCA TCA ACT CTG AAG } \\
\text { TTG ATA ATT TTA GCT-3' }\end{array}$ & $\begin{array}{l}\text { 5'-AAT GTT TCA ACA CCA ATT CCG CTG } \\
\text { CCG TTA ATT CTT TAA-3' }\end{array}$ \\
\hline T7 promoter & 5'-TAA TAC GAC TCA CTA TAG-3' & \\
\hline
\end{tabular}

changes could directly result in a shift to cancer, or a genetic change may be more indirectly linked. Clustering allows us to look at genetic changes that can be grouped together. It throws out a notion that all genetic changes are independent events. With the appropriate statistics, we can then discover differentially regulated pathways, processes, and cellular components, identify new members, and validate differential expression in these groups. So, we attempted to see if there were any alterations in the pathways.

In the recent past, knowledge of differential gene expression has helped to understand the molecular mechanisms that drive AD pathogenesis, HIV infection, and several others (Liang et al. 2008; Mantelingu et al. 2007). A heat map of transcript levels was created for the complete rat genome to display those statistically significant $(P$ value $<0.05$ with multiple testing corrections applied) (Fig. 1). Fold change used for upregulation and downregulation was 0.8 in each of the replicates and was $>1$ in the geometrical mean fold of the replicated samples. Normalized expression signals were represented on a log scale wherein colder colors correspond to lower levels of expression and warmer colors correspond to higher levels of expression. Heat maps were generated with Gene cluster v2.0 by Genotypic technologies. Figure $1 \mathrm{a}-\mathrm{c}$ shows comparisons of 
Fig. 2 Heat map of selected differentially upregulated genes. A heat map was created to display those statistically significant genes ( $P$ value $<0.05$ with multiple testing corrections applied) upregulated genes having fold change more than 1.55 in second week. Normalized expression signals are represented on a log scale for which colder colors correspond to lower levels of expression and warmer colors correspond to higher levels of expression. Genes were clustered and heat maps were generated using Cluster v3.0/ TreeView (de Hoon et al. 2004; Eisen et al. 1998)

expression $1 \mathrm{~W}$ with 2, 3, and $4 \mathrm{~W}$ as in set 1 , set 2, and set 3 , respectively. As this data was very exhaustive, we selected the upregulated genes with fold change $>1.55$ in the second week and $P$ value $<0.05$. This search resulted in identifying genes 157 genes. The heatmap was shown in Fig. 2, and the gene ontology-based functional classification was given in Fig. 3. The GO classification was performed by online available "PANTHER Classification System" (http://www.pantherdb. org/) (Mi et al. 2005; Thomas et al. 2003). We have selected the following six genes-A2m, Gna14, Gria1, Masp1, Npy, and Slit2, and the expression patterns were further validated by real-time PCR.

\section{Quantitative analysis of gene expression}

Expression of genes of interest in vitro aged rat brain CGNs is shown in Fig. 4. Quantitative analysis of gene expression in 2, 3, and $4 \mathrm{~W}$ was compared to $1 \mathrm{~W}$ using $2^{-\Delta \Delta \mathrm{CT}}$ method (Livak and Schmittgen 2001). Comparative CT method was employed to evaluate the gene transcript pattern in ageing cultures. q-RT PCR analysis reveals significant increase in relative expression of all genes through the weeks as per statistical analysis, oneway ANOVA (Tukey's post hoc test) $\left({ }^{*} P<0.05\right.$, $* * P<0.01, * * * P<0.001)$, where $1 \mathrm{~W}$ healthy CGNs were taken as control. Values are represented as mean $\pm \mathrm{SD}$ and $n=6$. Results in Fig. 5a, b show semiquantitative gene expression of A2m, Gna14, Grial, Masp1, Npy, Slit2, and Glb1. All the genes showed significant increase in expression at 2, 3, and $4 \mathrm{~W}$ in culture compared to $1 \mathrm{~W}$. Semi-quantitative analysis was done to ensure single product amplification.

\section{Cell viability assay}

As described by Bhanu et al. (2010), CGNs showed viability until the fifth week. Hence, in this study, we analyzed the viability of CGNs when specific genes are knockdown at third week in culture. Results in Fig. 6

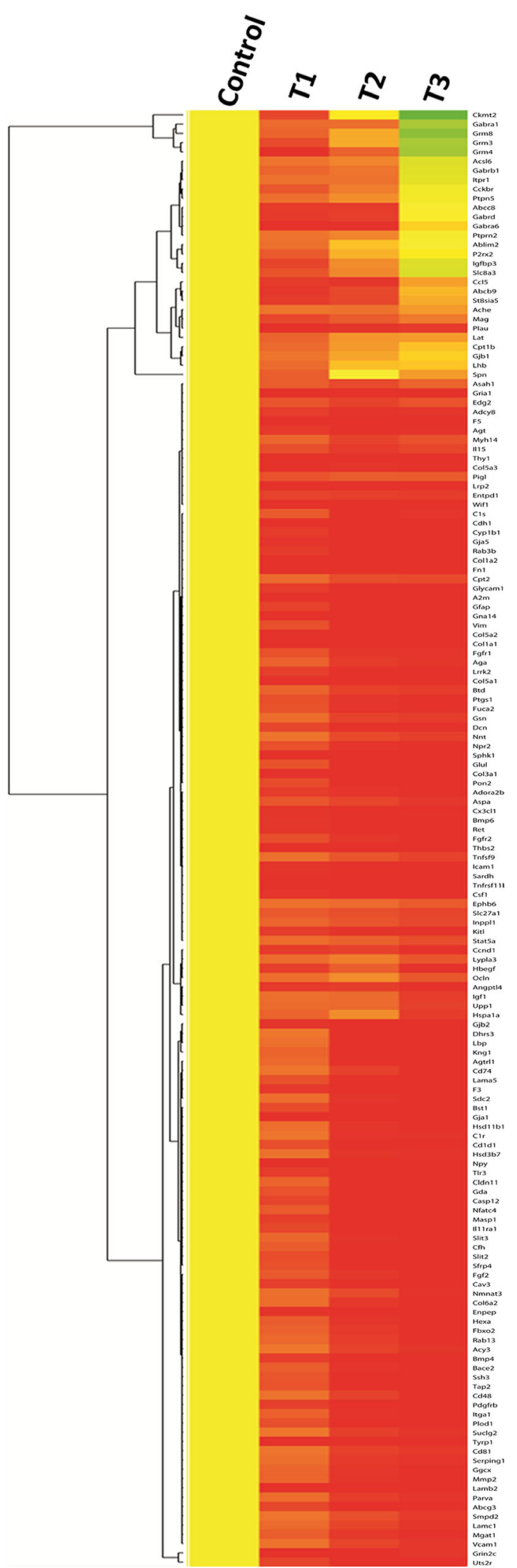




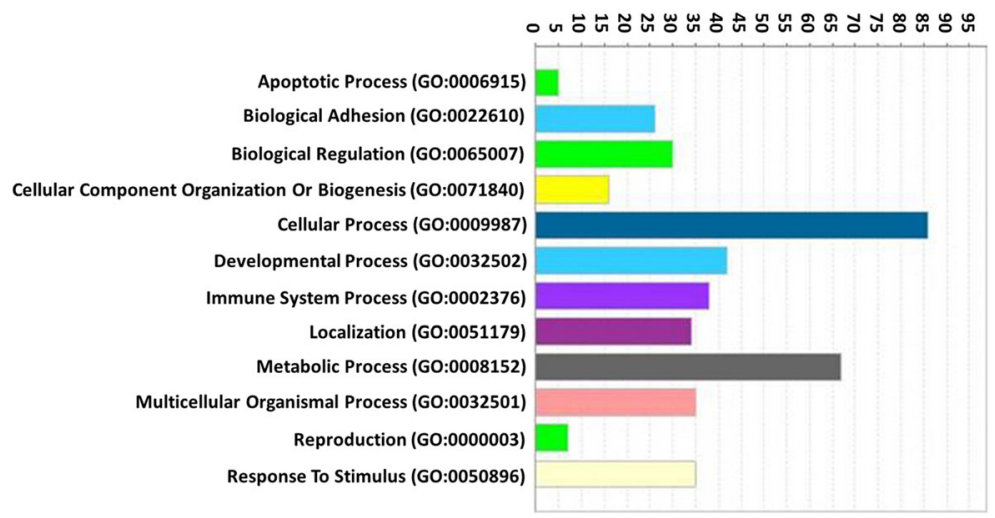

Fig. 3 Gene Ontology Classification of differentially expressed genes based on function. Gene Ontology of microarray differentials representing number of genes downregulated and upregulated in ageing CGNs from 1 to $4 \mathrm{~W}$ is shown in the bar chart. Fold

shows cytotoxicity detected in terms of reduction of MTT in ageing CGNs. Results are expressed as mean
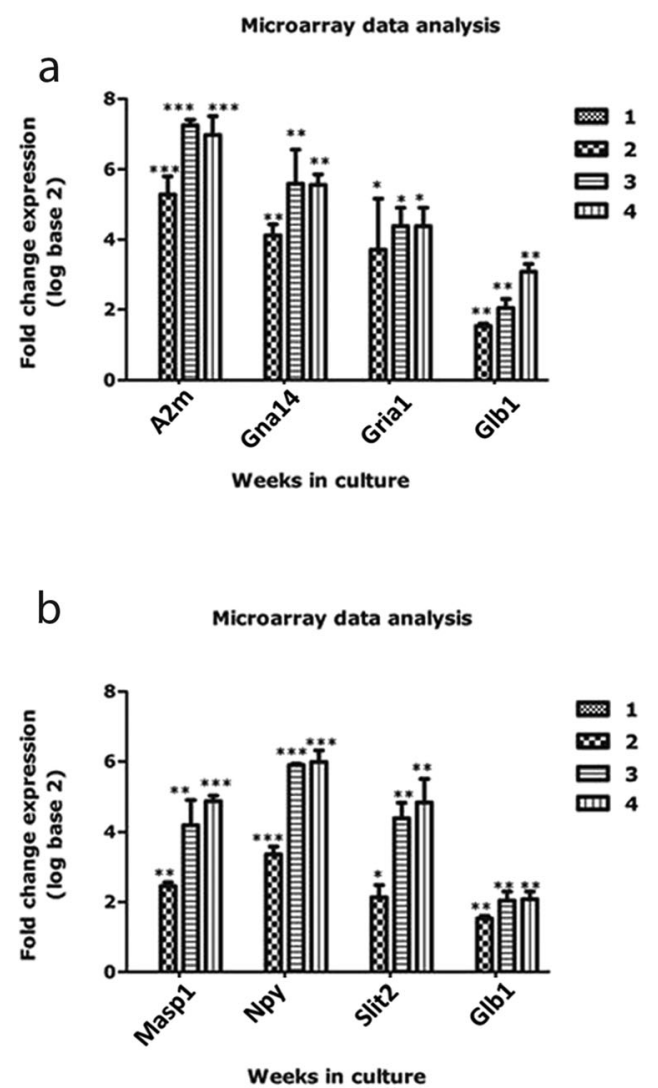

Fig. 4 Validation of differential gene expression by qPCR. Panels $\mathbf{a}$ and $\mathbf{b}$ show fold change expression by microarray analysis. Panels $\mathbf{c}$ and $\mathbf{d}$ depict validation by q-RT PCR of genes-A2m, Gna14, Gria1, Masp1, Npy, Slit2, and Glb1. q-RT PCR analysis reveals significant increase in relative expression of all genes change value of 0.8 and $P$ value $<0.05$ was considered to be statistically significant. The GO classification was performed by "PANTHER Classification System" (http://www.pantherdb.org/)

\pm SD (three replicates in two independent experiments). Cell viability in first week was considered as $100 \%$.
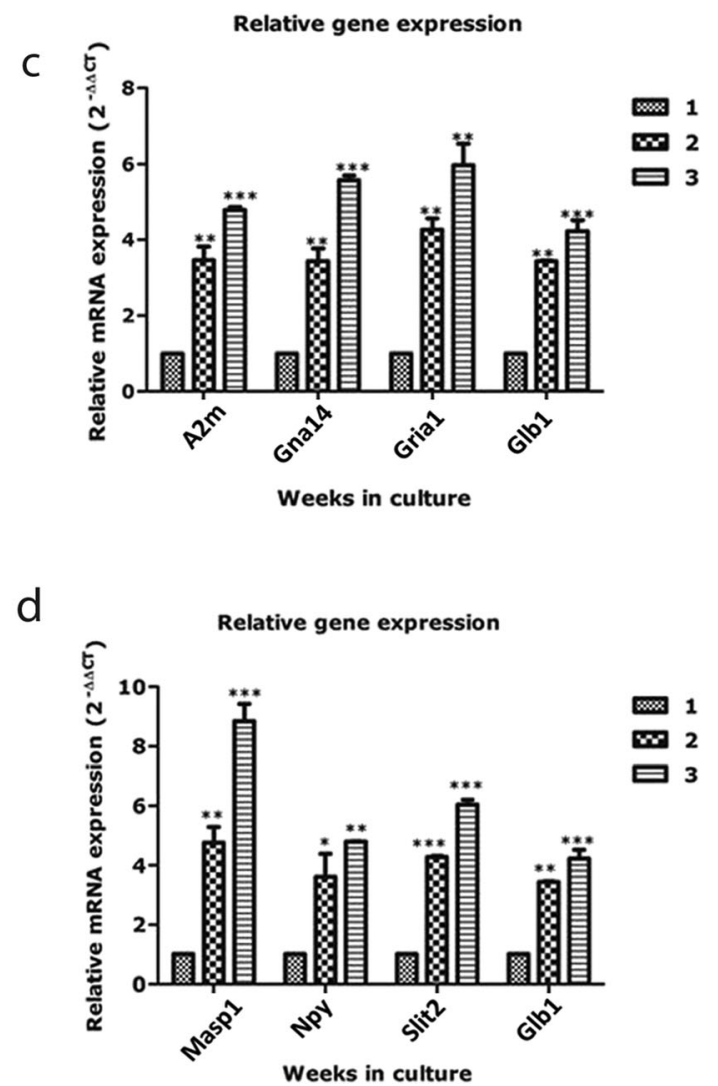

through the weeks as per statistical analysis, one-way ANOVA (Tukey's post hoc test) $\left({ }^{*} P<0.05,{ }^{*} P<0.01,{ }^{* * *} P<0.001\right) .1 \mathrm{~W}$ healthy CGNs were taken as control. Values are represented as mean $\pm \mathrm{SD}$ and $n=6$. Comparative CT method was employed to evaluate the gene transcript pattern in ageing cultures 
A semi quantitative analysis

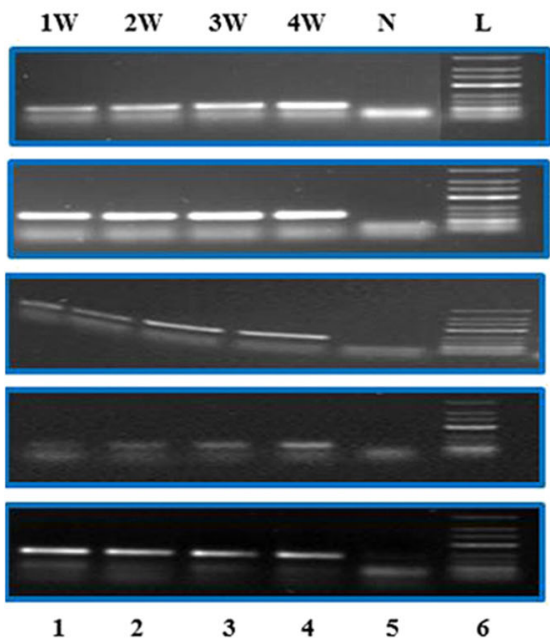

BP

$\mathrm{A} 2 \mathrm{~m}$

128

Gna14

147

Gria1

167

Glb1

118

$18 \mathrm{~s}$

200

Fig. 5 Semi quantitative PCR analysis. Panels a and $\mathbf{b}$ show semiquantitative gene expression of A2m, Gna14, Gria1, Masp1, Npy, Slit2, and Glb1. All the genes showed significant increased

Values are presented as a percentage of activity in control cells. Cell viability markedly decreased by $40 \%$ in second week, $20 \%$ by third week, and was then stable in fourth week by exhibiting $10 \%$ viability. Slit 2 and Npy downregulated cells showed marked increase in cell viability until sixth week. Thus, suggesting that the survival time by 1 week $(-16 \%)$ in Slit2, Npy $\bar{C}$ GNs compared to untransfected control. It is to be noted that CGNs in untransfected control as well as A2m, Gna1,

Fig. 6 Figure shows cytotoxicity detected by reduction of MTT in ageing CGNs. Results are expressed as mean $\pm \mathrm{SD}$ (three replicates in two independent experiments). Cell viability in first week was considered as $100 \%$. Values are presented as a percentage of activity in control cells. Cell viability is compared at every week based on MTT values presented. The results showed a marked increase in cell viability in Npy and Slit2 downregulated cells compared to control, when knockdown was done at third week in culture
B Semi quantitative analysis

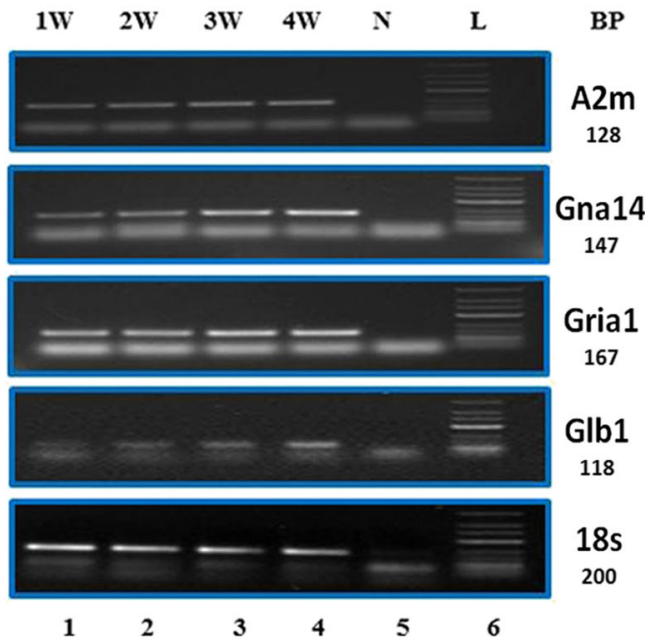

expression in 2, 3, and $4 \mathrm{~W}$ over $1 \mathrm{~W}$. Lanes $1-4$ correspond to 1 to $4 \mathrm{~W}$ transcript levels, lane 5 is no template control (NTC), and lane 6 is $50 \mathrm{bp}$ low range ladder

Gria1, Masp1 , Glb1 cells could not survive after 5 weeks and hence was not included in sixth week time point in Fig. 6.

\section{Expression level of topo II $\beta$}

Expression of Topo II $\beta$ has known to be decreased during in vitro ageing (Bhanu et al. 2010). The fold change expression of Topo II $\beta$ as assessed by

\section{MTT assay}

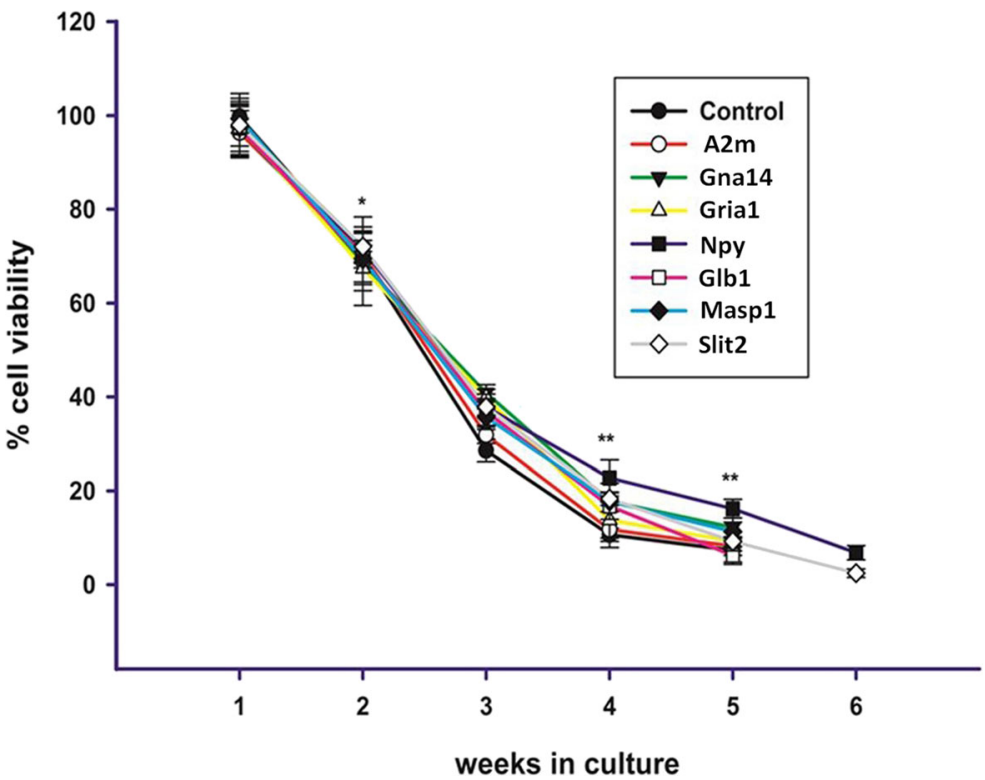


quantitative real-time PCR reveals significant decrease in relative expression of Topo II $\beta$ through the weeks (Fig. 7). Analysis of expression levels of Topo II $\beta$ in Slit2 and Npy downregulated CGNs showed a slight increase in the level of expression of Topo II $\beta$ in Slit2 and Npy downregulated cells when compared to control (untransfected).

\section{Discussion}

CGNs are the smallest neurons and also constitute the largest homogenous population in the human brain. CGNs have proven invaluable in uncovering the signaling pathways governing neuronal migration, differentiation, and survival (Contestabile 2002). Upon receiving signals from multiple mossy fibers, CGNs respond. The combination of multiple inputs results in cerebellum being able to make precise distinction between the input patterns (Marr 1969). Studies of neuronal apoptosis have frequently relied on cultures of granule neurons, exploiting their responses to activity and growth factor deprivation as well as oxidative stress. These studies have led to the identification of key neuroprotective molecules including insulin-like growth factor 1, myocyte enhancer factor 2, and many others (D’Mello et al. 1993; Li et al. 2001). Loss of CGNs is associated with punctate deposits of prion proteins in Creutzfeldt-Jakob disease (Faucheux et al. 2009). Mutant prion proteins $(\mathrm{PrP})$ suppress glutaminergic neurotransmission by reducing the number of functional channels in
CGNs (Senatore et al. 2012). Hence, owing to the varied roles of CGNs, it appears that detailed gene expression profiling of ageing CGNs might provide an important clue to understand and delay senescence.

About $20-40 \%$ of cortical, hippocampal and peripheral neurons and $40-80 \%$ of Purkinje neurons in the myenteric plexus from six C57B1 old mice showed severe DNA damage, high ROS, oxidative damage, IL6 production, heterochromatinization, and SA- $\beta$-Gal activity (Jurk et al. 2012). Further, in this study, we have found that aberrant expression of genes in categories - tumor suppressor, antiapoptotic, apoptotic, topoisomerases, BER pathway, and polymerases (Fig. 3) might be responsible for senescence. Senescent CGNs act as a potential causal factor for ageing in mammals (Baker et al. 2008; Herbig et al. 2006). Despite long established evidence for significant DNA damage in postmitotic neurons (Gupta et al. 2012), the possibility of postmitotic cells developing senescence-like phenotype has not been evaluated before.

Significant gene expression of A2m in CGNs (Fig. 4) suggests that it may confer neuroprotection against possible risk of $\mathrm{AD}$ and, hence, may prove to be a potential marker for senescence in ageing CGNs. Mannanbinding lectin, serine peptidase 1 (Masp1), a serine protease that plays a role in the mannan-binding lectin complement pathway (RGD). This gene encodes a protein that exhibits calcium ion binding, involved in complement activation. Methionine deficiency co-treated with choline deficiency and folic acid deficiency resulted in lowered expression MASP mRNA (Tryndyak
Fig. 7 Expression of Topo II $\beta$ in Slit2 and Npy downregulated cells. Relative mRNA levels of Topo II $\beta$ in downregulated cells were determined by real-time PCR. Genes show a significant increase in relative gene expression through the weeks as per statistical analysis; $1 \mathrm{~W}$ healthy CGNs were taken as control

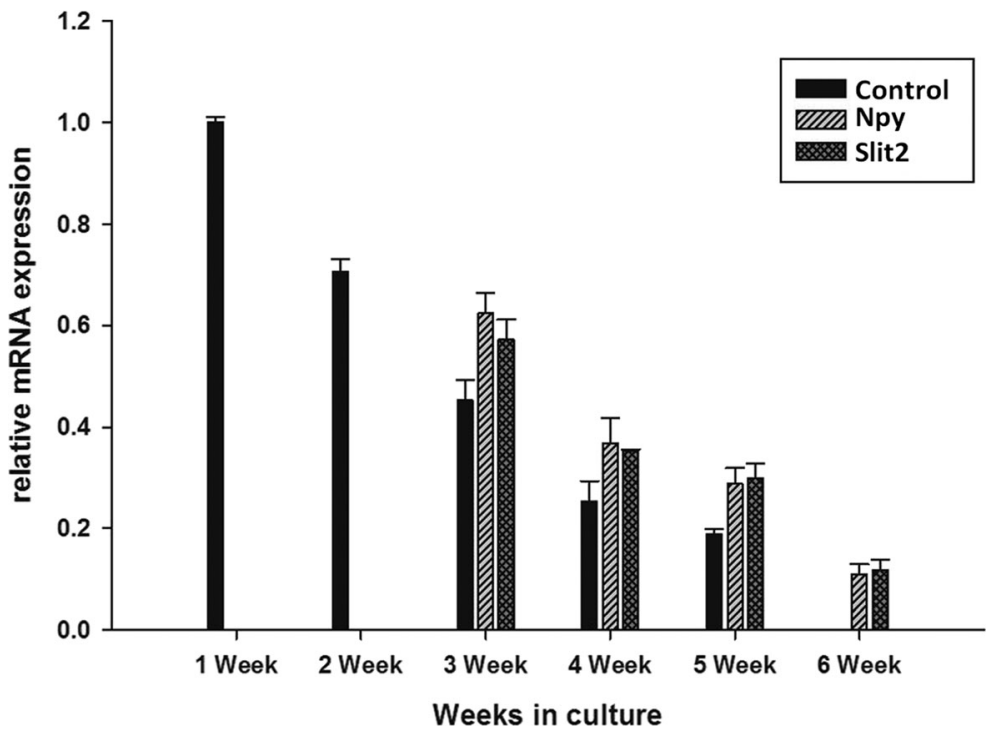


et al. 2011). In this study, we identified statistically significant upregulated expression of $\mathrm{G}$ proteins, Grial and Gna14 as well as of Npy and Slit2 (Figs. 4 and 5). Guanine nucleotide-binding protein, alpha 14 abbreviated as Gna14, exhibits GTPase activity involved in signal transduction and protein amino acid ADP ribosylation (RGD). It participates in G protein-mediated signaling pathway and belongs to the q-family. Blalock et al. 1999 reported lowered $\mathrm{G}$ protein-mediated regulation and shift in calcium channel types with ageing hippocampal cultures (Blalock et al. 1999). Moreover, forebrain specific inactivation of Gq/ G11 family G proteins results in agedependent epilepsy and impaired endocannabinoid formation (Wettschureck et al. 2006) implicating that Gq family negatively regulates neuronal excitability. This suggests that Gna14 can emerge as a marker with neuroprotective role. Glutamate receptor ionotropic AMPA 1 abbreviated as Grial encodes a protein exhibiting ionotropic glutamate receptor activity and $\mathrm{G}$ protein $\alpha$ subunit binding and is known to be associated with the CNS. A marked increase in the Grial subunit mRNA expression in adult hippocampal neurons during CNS inflammation was reported (Galic et al. 2009). Further, in cortical neurons during intrauterine growth retardation, suppressed expression of glutamate receptors such as Grial and GluN2A was also reported (Ninomiya et al. 2010) which implicates its role in schizophrenia-like behavior. Borbely et al. 2009 have shown increased expression and modification of Grialmediated signal transmission in the rat hippocampus following repeated brief seizures (Borbely et al. 2009). Slit homolog 2 (Drosophila) encodes a protein that exhibits heparin sulfate proteoglycan binding, GTPase inhibitor activity, and has been reported to be involved in brain development. Since glypican-1 ligands are synthesized by hippocampal-pyramidal cells and CGNs, Slit2 family proteins being functional ligands of glypican- 1 in nervous tissue suggests that their interaction may be critical for certain stages of CNS histogenesis (Liang et al. 1999). Slit2 homolog showed altered expression in this study. Neuropeptide Y abbreviated as Npy encodes a protein which exhibits neuropeptide $Y$ receptor binding with $G$ protein coupled receptor binding (RGD) and is known to be associated with cerebral hemorrhage and may be involved in its pathogenesis. Donner et al. and Xu et al. have reported involvement of Npy in determining predisposition to anxiety disorders (Donner et al. 2012; Xu et al. 2004). Decreased cerebrospinal fluid Npy in patients with depression implicates that impaired Npy signaling could be involved in the pathophysiology of anxiety and depression (Heilig et al. 2004). So, it may be explored further as a marker for senescence.

These genes were further explored, and the knockdown study was done to see if these genes at the time of their increase in CGNs would delay senescence. Viability studies showed the importance of Slit 2 and Npy for extended viability in CGNs in vitro. Different molecular markers which are established in vitro ageing such as $\beta$ galactosidase assay and repair efficiency had been used to study the downregulated CGNs. The study showed significant increase in repair gene expression in Slit2 and Npy downregulated cells, when compared to control cells in vitro ageing. The expression of Topo II $\beta$, which is established as a biomarker in vitro (Bhanu et al. 2010), has been checked in Slit2 and Npy downregulated cells. The expression of Topo II $\beta$ showed a slight increase indicating its importance in regulation of repair gene expression and connection between expression of Slit2 and Npy in its regulation during ageing in vitro.

\section{Conclusion}

In this study, a detailed level of steady-state expression of all rodent genes and transcripts in ageing CGNs was presented. A thorough analysis of upregulated genes during aging of CGNs followed by validation using genespecific silencing exhibited the importance of Npy and Slit2 gene expression improved survival of CGNs. Further, downregulation of Npy and Slit2 showed increase in Topo II $\beta$ levels, thus suggesting that Npy, Slit2, and Topo II $\beta$ potential targets in regulating senescence and survival during ageing and neurodegeneration.

Acknowledgments Work incorporated is funded under research project sponsored by the Department of Biotechnology, Government of India and UGC FRPS one-time grant of AKK. KPG was an ICMR research fellow. PKD and AC are DBT research fellows.

\section{References}

Baker DJ et al (2008) Opposing roles for p16Ink4a and p19Arf in senescence and ageing caused by BubR1 insufficiency. Nat Cell Biol 10:825-836. doi:10.1038/ncb1744

Beausejour CM, Krtolica A, Galimi F, Narita M, Lowe SW, Yaswen P, Campisi J (2003) Reversal of human cellular senescence: roles of the p53 and p16 pathways. EMBO J 22:4212-4222. doi:10.1093/emboj/cdg417 
Bhanu MU, Mandraju RK, Bhaskar C, Kondapi AK (2010) Cultured cerebellar granule neurons as an in vitro aging model: topoisomerase IIbeta as an additional biomarker in DNA repair and aging. Toxicol in Vitro Int $\mathrm{J}$ Publ Assoc BIBRA 24:1935-1945. doi:10.1016/j.tiv.2010.08.003

Blalock EM, Porter NM, Landfield PW (1999) Decreased Gprotein-mediated regulation and shift in calcium channel types with age in hippocampal cultures. J Neurosci Off J Soc Neurosci 19:8674-8684

Borbely S et al (2009) Modification of ionotropic glutamate receptor-mediated processes in the rat hippocampus following repeated, brief seizures. Neuroscience 159:358-368. doi: 10.1016/j.neuroscience.2008.12.027

Braig M, Schmitt CA (2006) Oncogene-induced senescence: putting the brakes on tumor development. Cancer Res 66:28812884. doi:10.1158/0008-5472.CAN-05-4006

Campisi J, d'Adda di Fagagna F (2007) Cellular senescence: when bad things happen to good cells. Nat Rev Mol Cell Biol 8: 729-740

Chang BD, Swift ME, Shen M, Fang J, Broude EV, Roninson IB (2002) Molecular determinants of terminal growth arrest induced in tumor cells by a chemotherapeutic agent. Proc Natl Acad Sci U S A 99:389-394. doi:10.1073/pnas. 012602599

Chen QM, Liu J, Merrett JB (2000) Apoptosis or senescence-like growth arrest: influence of cell-cycle position, p53, p21 and bax in $\mathrm{H} 2 \mathrm{O} 2$ response of normal human fibroblasts. Biochem J 347:543-551

Chung HY et al (2009) Molecular inflammation: underpinnings of aging and age-related diseases. Ageing Res Rev 8:18-30. doi:10.1016/j.arr.2008.07.002

Collado M, Serrano M (2006) The power and the promise of oncogene-induced senescence markers. Nat Rev Cancer 6: $472-476$

Contestabile A (2002) Cerebellar granule cells as a model to study mechanisms of neuronal apoptosis or survival in vivo and in vitro. Cerebellum 1:41-55. doi:10.1080/ 147342202753203087

Davalos AR, Coppe JP, Campisi J, Desprez PY (2010) Senescent cells as a source of inflammatory factors for tumor progression. Cancer Metastasis Rev 29:273-283. doi:10.1007/ s10555-010-9220-9

de Hoon MJ, Imoto S, Nolan J, Miyano S (2004) Open source clustering software. Bioinformatics 20:1453-1454. doi:10. 1093/bioinformatics/bth078

Di Micco R, Cicalese A, Fumagalli M, Dobreva M, Verrecchia A, Pelicci PG, di Fagagna F (2008) DNA damage response activation in mouse embryonic fibroblasts undergoing replicative senescence and following spontaneous immortalization. Cell Cycle 7:3601-3606

Dimri GP et al (1995) A biomarker that identifies senescent human cells in culture and in aging skin in vivo. Proc Natl Acad Sci U S A 92:9363-9367

D’Mello SR, Galli C, Ciotti T, Calissano P (1993) Induction of apoptosis in cerebellar granule neurons by low potassium: inhibition of death by insulin-like growth factor I and cAMP. Proc Natl Acad Sci U S A 90:10989-10993

Donner J et al (2012) Support for involvement of glutamate decarboxylase 1 and neuropeptide $\mathrm{Y}$ in anxiety susceptibility. Am J Med Genet B Neuropsychiatr Genet 159B:316-327. doi:10.1002/ajmg.b.32029
Donze O, Picard D (2002) RNA interference in mammalian cells using siRNAs synthesized with T7 RNA polymerase. Nucleic Acids Res 30, e46

Eisen MB, Spellman PT, Brown PO, Botstein D (1998) Cluster analysis and display of genome-wide expression patterns. Proc Natl Acad Sci U S A 95:14863-14868

Faucheux BA et al (2009) Loss of cerebellar granule neurons is associated with punctate but not with large focal deposits of prion protein in Creutzfeldt-Jakob disease. J Neuropathol Exp Neurol 68:892-901. doi:10.1097/NEN. 0b013e3181af7f23

Franceschi C, Bonafe M, Valensin S, Olivieri F, De Luca M, Ottaviani E, De Benedictis G (2000) Inflamm-aging. An evolutionary perspective on immunosenescence. Ann N Y Acad Sci 908:244-254

Funayama R, Ishikawa F (2007) Cellular senescence and chromatin structure. Chromosoma 116:431-440. doi:10.1007/ s00412-007-0115-7

Galic MA, Riazi K, Henderson AK, Tsutsui S, Pittman QJ (2009) Viral-like brain inflammation during development causes increased seizure susceptibility in adult rats. Neurobiol Dis 36:343-351. doi:10.1016/j.nbd.2009.07.025

Gupta KP, Swain U, Rao KS, Kondapi AK (2012) Topoisomerase IIbeta regulates base excision repair capacity of neurons. Mech Ageing Dev 133:203-213. doi:10.1016/j.mad.2012. 03.010

Hayflick L (1965) The limited in vitro lifetime of human diploid cell strains. Exp Cell Res 37:614-636

Heilig M et al (2004) Decreased cerebrospinal fluid neuropeptide Y (NPY) in patients with treatment refractory unipolar major depression: preliminary evidence for association with preproNPY gene polymorphism. J Psychiatr Res 38: 113-121

Herbig U, Jobling WA, Chen BP, Chen DJ, Sedivy JM (2004) Telomere shortening triggers senescence of human cells through a pathway involving ATM, p53, and p21(CIP1), but not p16(INK4a). Mol Cell 14:501-513

Herbig U, Ferreira M, Condel L, Carey D, Sedivy JM (2006) Cellular senescence in aging primates. Science 311:1257

Jeyapalan JC, Sedivy JM (2008) Cellular senescence and organismal aging. Mech Ageing Dev 129:467-474. doi:10.1016/j. $\operatorname{mad}$ 2008.04.001

Jurk D et al (2012) Postmitotic neurons develop a p21-dependent senescence-like phenotype driven by a DNA damage response. Aging Cell 11:996-1004. doi:10.1111/j.1474-9726. 2012.00870.x

Kosar M, Bartkova J, Hubackova S, Hodny Z, Lukas J, Bartek J (2011) Senescence-associated heterochromatin foci are dispensable for cellular senescence, occur in a cell type- and insult-dependent manner and follow expression of p16(ink4a). Cell Cycle 10:457-468

Lawless C, Wang C, Jurk D, Merz A, Zglinicki T, Passos JF (2010) Quantitative assessment of markers for cell senescence. Exp Gerontol 45:772-778. doi:10.1016/j.exger.2010.01.018

Li M et al (2001) Myocyte enhancer factor 2A and 2D undergo phosphorylation and caspase-mediated degradation during apoptosis of rat cerebellar granule neurons. J Neurosci Off J Soc Neurosci 21:6544-6552

Liang Y, Annan RS, Carr SA, Popp S, Mevissen M, Margolis RK, Margolis RU (1999) Mammalian homologues of the drosophila slit protein are ligands of the 
heparan sulfate proteoglycan glypican-1 in brain. J Biol Chem 274:17885-17892

Liang WS et al (2008) Altered neuronal gene expression in brain regions differentially affected by Alzheimer's disease: a reference data set. Physiol Genomics 33:240-256. doi:10.1152/ physiolgenomics.00242.2007

Lin AW, Barradas M, Stone JC, van Aelst L, Serrano M, Lowe SW (1998) Premature senescence involving p53 and p16 is activated in response to constitutive MEK/MAPK mitogenic signaling. Genes Dev 12:3008-3019

Livak KJ, Schmittgen TD (2001) Analysis of relative gene expression data using real-time quantitative PCR and the 2(-delta delta C(T)). Method Methods 25:402-408. doi:10.1006/ meth.2001.1262

Mandraju RK, Kannapiran P, Kondapi AK (2008) Distinct roles of topoisomerase II isoforms: DNA damage accelerating alpha, double strand break repair promoting beta. Arch Biochem Biophys 470:27-34. doi:10.1016/j.abb.2007.10.017

Mantelingu K et al (2007) Specific inhibition of p300-HAT alters global gene expression and represses HIV replication. Chem Biol 14:645-657

Marr D (1969) A theory of cerebellar cortex. J Physiol 202:437470

Mi H et al (2005) The PANTHER database of protein families, subfamilies, functions and pathways. Nucleic Acids Res 33: D284-288. doi:10.1093/nar/gki078

Milligan JF, Uhlenbeck OC (1989) Synthesis of small RNAs using T7 RNA polymerase. Methods Enzymol 180:51-62

Minamino T, Komuro I (2007) Vascular cell senescence: contribution to atherosclerosis. Circ Res 100:15-26

Mosmann T (1983) Rapid colorimetric assay for cellular growth and survival: application to proliferation and cytotoxicity assays. J Immunol Methods 65:55-63

Munro J, Barr NI, Ireland H, Morrison V, Parkinson EK (2004) Histone deacetylase inhibitors induce a senescence-like state in human cells by a p16-dependent mechanism that is independent of a mitotic clock. Exp Cell Res 295:525-538. doi: 10.1016/j.yexcr.2004.01.017

Nakamura AJ, Chiang YJ, Hathcock KS, Horikawa I, Sedelnikova OA, Hodes RJ, Bonner WM (2008) Both telomeric and nontelomeric DNA damage are determinants of mammalian cellular senescence. Epigenetics Chromatin 1:6. doi:10. $1186 / 1756-8935-1-6$

Ninomiya $\mathrm{M}$ et al (2010) Cortical neurons from intrauterine growth retardation rats exhibit lower response to neurotrophin BDNF. Neurosci Lett 476:104-109. doi:10. 1016/j.neulet.2010.03.082

Ressler S, Bartkova J, Niederegger H, Bartek J, ScharffetterKochanek K, Jansen-Durr P, Wlaschek M (2006) p16INK4A is a robust in vivo biomarker of cellular aging in human skin. Aging Cell 5:379-389

Rodier F, Campisi J, Bhaumik D (2007) Two faces of p53: aging and tumor suppression. Nucleic Acids Res 35:7475-7484

Senatore A et al (2012) Mutant PrP suppresses glutamatergic neurotransmission in cerebellar granule neurons by impairing membrane delivery of VGCC alpha(2)delta-1 Subunit. Neuron 74:300-313. doi:10.1016/j.neuron.2012.02.027

Serrano M, Lin AW, McCurrach ME, Beach D, Lowe SW (1997) Oncogenic ras provokes premature cell senescence associated with accumulation of p53 and p16INK4a. Cell 88:593-602

Sikora E, Arendt T, Bennett M, Narita M (2011) Impact of cellular senescence signature on ageing research. Ageing Res Rev 10: 146-152. doi:10.1016/j.arr.2010.10.002

Tchkonia T et al (2010) Fat tissue, aging, and cellular senescence. Aging Cell 9:667-684. doi:10.1111/j.1474-9726.2010. 00608.x

Tepper CG, Seldin MF, Mudryj M (2000) Fas-mediated apoptosis of proliferating, transiently growth-arrested, and senescent normal human fibroblasts. Exp Cell Res 260:9-19. doi:10. 1006/excr.2000.4990

Thibault O, Hadley R, Landfield PW (2001) Elevated postsynaptic $[\mathrm{Ca} 2+] \mathrm{i}$ and L-type calcium channel activity in aged hippocampal neurons: relationship to impaired synaptic plasticity. J Neurosci Off J Soc Neurosci 21:9744-9756

Thomas PD et al (2003) PANTHER: a library of protein families and subfamilies indexed by function. Genome Res 13:21292141. doi:10.1101/gr.772403

Tryndyak VP, Han T, Muskhelishvili L, Fuscoe JC, Ross SA, Beland FA, Pogribny IP (2011) Coupling global methylation and gene expression profiles reveal key pathophysiological events in liver injury induced by a methyl-deficient diet. Mol Nutr Food Res 55:411-418. doi:10.1002/mnfr.201000300

Villeponteau B (1997) The heterochromatin loss model of aging. Exp Gerontol 32:383-394

Wada T et al (2004) MKK7 couples stress signalling to G2/M cellcycle progression and cellular senescence. Nat Cell Biol 6: 215-226. doi:10.1038/ncb1098

Wang C, Jurk D, Maddick M, Nelson G, Martin-Ruiz C, von Zglinicki T (2009) DNA damage response and cellular senescence in tissues of aging mice. Aging Cell 8:311-323. doi:10.1111/j.1474-9726.2009.00481.x

Wettschureck N et al (2006) Forebrain-specific inactivation of Gq/ G11 family G proteins results in age-dependent epilepsy and impaired endocannabinoid formation. Mol Cell Biol 26: 5888-5894. doi:10.1128/MCB.00397-06

Wilkin GP (1995) Neural cell culture: a practical approach. Oxford University Press, New York. http://searchworks.stanford.edu/ view/3146133

Xu ZQ, Chen ME, Jiang XJ, Wang JZ (2004) Changes of neuropeptide $\mathrm{Y}$ activity in plasma and brain tissue during intracerebral hemorrhage in rats. Zhongguo Wei Zhong Bing Ji Jiu Yi Xue 16:218-220

Yang DG, Liu L, Zheng XY (2008) Cyclin-dependent kinase inhibitor p16(INK4a) and telomerase may co-modulate endothelial progenitor cells senescence. Ageing Res Rev 7: 137-146. doi:10.1016/j.arr.2008.02.001

Yoon IK et al (2004) Exploration of replicative senescenceassociated genes in human dermal fibroblasts by cDNA microarray technology. Exp Gerontol 39:1369-1378. doi: 10.1016/j.exger.2004.07.002

Zhang H, Pan KH, Cohen SN (2003) Senescence-specific gene expression fingerprints reveal cell-type-dependent physical clustering of up-regulated chromosomal loci. Proc Natl Acad Sci U S A 100:3251-3256. doi:10.1073/pnas.2627983100

Zhu J, Woods D, McMahon M, Bishop JM (1998) Senescence of human fibroblasts induced by oncogenic Genes Dev.Raf. Genes Dev 12:2997-3007 